\title{
Comparative Study of Changing Pattern of Temperature for Various Periods of Time
}

\author{
${ }^{1}$ Mst. Ayrin Aktar, ${ }^{2}$ Kamalesh Chandra Roy \\ I' Lecturer, Department of Mathematics, Gono Bishwabidyalay, Savar-1344, Bangladesh) \\ ${ }^{2}$ (Associate Professor, Department of Mathematics, Begum Rokeya University, Rangpur-5400, Bangladesh)
}

\begin{abstract}
Temperature change plays a crucial role in global change sciences. In the past several decades, comprehensive findings have been achieved on temperature change in China for the past 100 years. Several time series have been created to illustrate the averaged surface air temperature for the country. The correlations of these series range from 0.73 to 0.97. It is also achieved in better data quality, wider spatial data coverage, improved homogeneity of time series, and enhanced reliability of findings. The results show an annual mean temperature increase by $0.78 \pm 0.27^{\circ} \mathrm{C}$ per 100 years in China for the period 1906-2005. After prolonging the period till 2007, it is found that 2007 is rated as the warmest year in the past 100 years. Although all the series, except one, reflect temperature changes in the eastern part of China before the 1930s, they represent the general temperature change in most parts of the country after the 1930s.
\end{abstract}

Keywords: Climatic change Equilibrium Fagus Late-Quaternary Palynology Picea Quebec

\section{Introduction}

Global warming becomes one of the most important environmental problems inthe 21 st century and the impacts of global warming are worldwide (Chan 2006)and Bangladesh is the one of most vulnerable country in the world (Richard 2012). Global warming is mainly caused by the increase of green house gases of the atmosphere (Houghton 2002). The assumption that increased greenhouse gas concentrations may lead to a rise in global temperatures first emerged in the 1960s (Peterson et al. 2008). The great majority of climate scientists now agree that the evidence for anthropogenic global warming is strong (Rosenberg et al. 2008). Predictions of average temperature changes and the economic costs of climate change are uncertain, but generally bleak: for increases of $5-6{ }^{\circ} \mathrm{C}$, which is a "Production as Usual" scenario, the predicted economic loss is 5-10\% of global GDP (Stern 2007). In Earths past there have been significant periods of global warming and cooling, with average global temperatures from some era higher than current temperatures (Zachos et al. 2001). Intergovernmental Panel on climate Change (IPCC) has reported in their fourth assessment report that global surface temperature increased $0.74 \pm 0.18^{\circ} \mathrm{C}$ during the 100 years ending in 2005 (IPCC 2007). It is also noted by IPCC (2007) that the rise of mean annual temperature will be $3.3^{\circ} \mathrm{C}$ per century. In the past, a number of studies have been carried out on trend of climate change in climatic parameters over Bangladesh. The pointed out that temperature trends has been changed (Chowdhury and Debsharma 1992; Mia 2003; Islam 2007). The reported mean annual temperature of Bangladesh has increased during the period of 1895-1980 at 0.310C over thepast two decades (Parathasarathy et al. 1987; Divya and Mehritra 1995). Using the 1961-1990 data for Bangladesh projected that annual mean maximum temperature will increaseto $0.40 \mathrm{C}$ and $0.730 \mathrm{C}$ by the year of 2050 and 2100 respectively (Karmakar and Shrestha 2000). In this context, it is essential to quantify changes of temperature in recent yearsbased on the historical data. This paper is going to study conducted on the long term changes of near surface air temperature of Bangladesh using data from historic period up to recent year and what government of Bangladesh should do due to climate change. This study represents both an extension of (Chowdhury and Debsharma 1992) and a continuation of (Islam 2008) with implications and policy framework. Where (Islam 2008) important questions such as implications, mitigation policy and adaptation to climate change remain unanswered. In Barisal has a tropical climate. In winter, there is much less rainfall in Barisal than in summer. This location is classified as Aw by Köppen and Geiger. In Barisal, the average annual temperature is $25.9{ }^{\circ} \mathrm{C}$. The average annual rainfall is $2184 \mathrm{~mm}$. Khulna is the third-largest city in Bangladesh. It is the administrative seat of Khulna Distict and Khulna Division. As of the 2008 census, the city has a population of 663,34 Khulna is an old river port located on the Rhupsa river. It is an important hub of Bangladeshi industry and hosts many national companies. It is served by port Mongla, the second largest seaport in the country.

It is also one of the two principal naval command centres of the Bangladesh Navey. A colonial steamboat service, including the fleet Tern, Osrich and Lepcha, continues to operate on the river route to the city. It is regarded as the gateway to the Sundarbans, the world's largest tidal forest and home of the Bengel Tiger. Khulna is also situated north of the historic Mosque city of Bagerhat, a UNESCO World heritage site. In Khulna, the average annual temperature is $27.9^{\circ} \mathrm{C}$. The average annual rainfall is $2189 \mathrm{~mm}$. 


\section{Data Set}

The results of our study are expected to be different from (Islam 2008) if we adopt data for a longer time period. The present investigation will use approximately 63 years of temperature data is provided by the BMD. Maximum, minimum and average daily temperature data of last sixty-three years (1948-2010) has been collected from 35 stations of BMD located all over the Bangladesh have been used in this study . Fig. 1 shows location of the BMD stations over Bangladesh. These stations are mainly located at the city center of an urban district. Trend analysis has been conducted on monthly average data for all the stations. Monthly average value for both last 63 years and last 21 years (1990-2010) has been stud

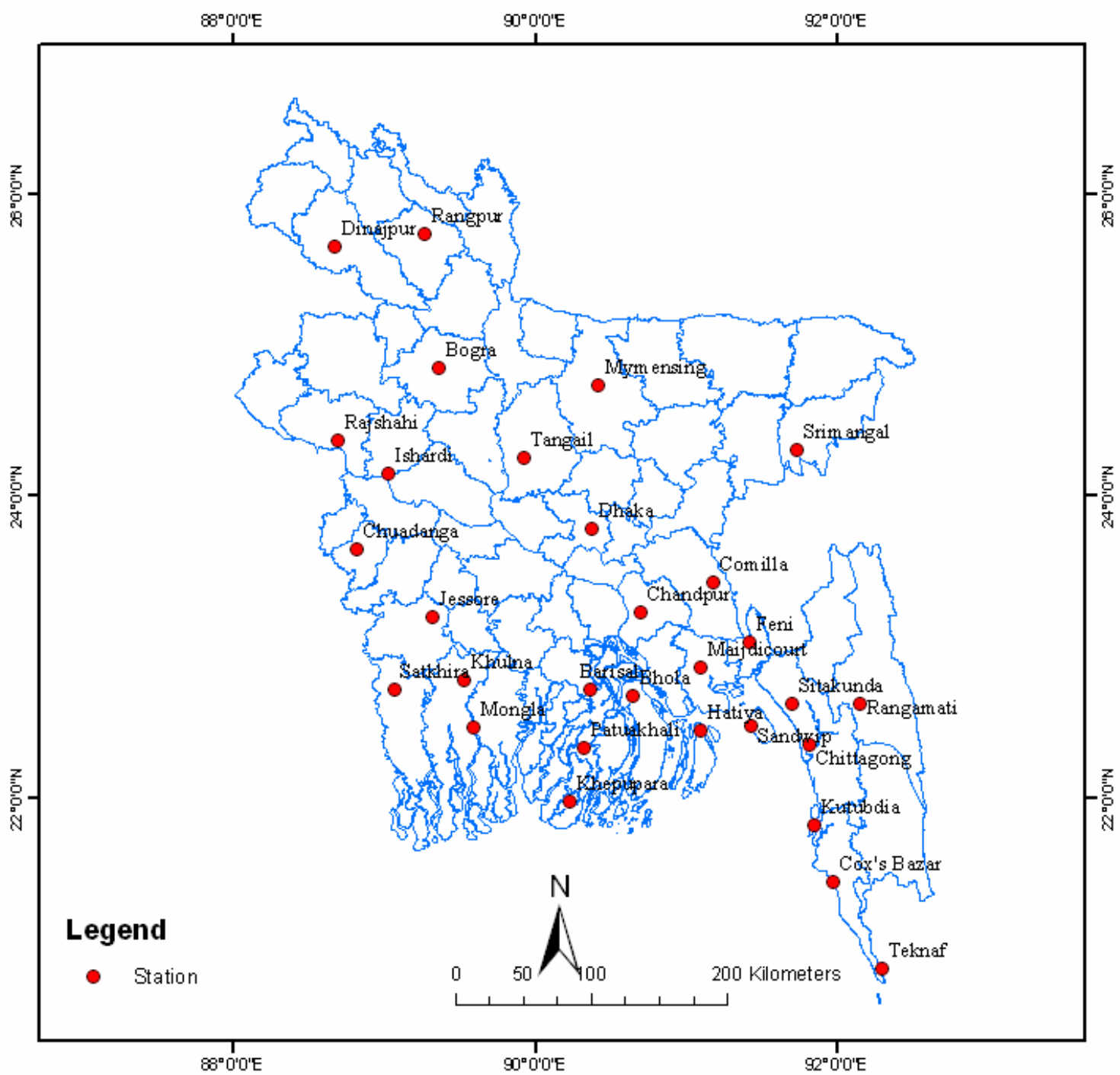

Fig. 1 Thirty five ground base measuring stations of Bangladesh Meteorological Department. Source (Islam 2008)

\section{Methodology}

Regression equation were formed in the form

$$
y=m t+b
$$

Where " $m$ " is the slope of the trend line and " $b$ " is the intercept of trend line with y-axis

Regression equation were formed in the form

$$
y=m t+b
$$

Where " $m$ " is the slope of the trend line and " $b "$ is the intercept of trend line with y-axis

$$
\begin{aligned}
& m=\frac{\sum t_{i} y_{i}-\sum t_{i} \sum y_{i}}{\sum t^{2}-\sum t_{i} \sum t_{i}} \\
& b=\bar{y}-m \bar{t}
\end{aligned}
$$


Where, $t_{i}$ is the independent variable, $\bar{t}$ is the average of the independent variable, $y_{i}$ is the dependable variable and $\bar{y}$ is the average of dependable variable. Coefficient of determination, $\mathrm{R}$-square $\left(R^{2}\right)$

of the trend vary between 0 and 1 . It can be found by using the following formula

Correlation coefficient

$$
R^{2}=1-\frac{S S_{\text {arr }}}{S_{\text {total }}}
$$

$$
r=\frac{\left[\sum\left(t_{i}-\bar{t}\right)\left(y_{i}-\bar{y}\right)\right]}{\sqrt{\sum\left(t_{i}-\bar{t}\right)^{2} \sum\left(\left(y_{i}-\bar{y}\right)\right)^{2}}}
$$

Long-term trend analyses were carried out for key meteorological parameters that might be influenced by global warming. There are many statistical methods for calculating trends, including parametric methods such as regression and t-test (e.g. Easterling et al. 1997; Karl et al. 1993) and non-parametric methods such as Mann-Kendall test (e.g. Qian and Giorgi, 2000; Quereda Sala et al. 2000). This study adopted the most commonly employed regression method and t-test (Easterling et al. 1997), a paper in IPCC (2001), and also (Karl et al. 1993). The long-term trend could then be inferred from the slopes of these straight lines. Two tailed t-test was applied to test the statistical significance of the trends at 5\% significance level.The test statistics $t$ for testing the null hypothesis $\mathrm{H} 0$ : trend $=0$ against the alternative hypothesis $\mathrm{H} 1$ : trend $\neq 0$, is given by:

$$
t=r \sqrt{\frac{n-2}{1-r^{2}}}
$$

Where $\mathrm{r}$ is the correlation coefficient and follows a t distribution with $\mathrm{n}-2$ degrees of freedom.

Monthly maximum, minimum and mean temperature shows a positive trend over Bangladesh. Increase of monthly maximum temperature is $0.600 \mathrm{C}$, monthly minimum temp is 1.39 0C and monthly mean temperature is $0.790 \mathrm{C}$ per 100 years. Maximum increase of monthly maximum temperature has occurred in November at $2.050 \mathrm{C}$ and monthly minimum temperature has occurred in February at $2.730 \mathrm{C}$ in 100 years. The highest increase of monthly maximum temperature has occurred as $1.10 \mathrm{C}$ per 100 years at Dhaka and monthly minimum temperature has occurred as -0.2 OC per 100 years at Rajshahi. It has clearly found that maximum temperature has been increased dramatically over the last 21 years period. Monthly maximum, minimum and mean temperature has shown positive increase with a rate of $4.490 \mathrm{C}, 2.980 \mathrm{C}$ and $2.060 \mathrm{C}$ per 100 years respectively during the period of last 21 years (1990-2010). Increase of winter temperature can reduce the environmental suitability for wheat, potato and other temperate crops grown in Rabi season. Implications for Agriculture and Fisheries; in Bangladesh, the largest demand for both surface and ground water is to support irrigation in the dry months. Changes in climate may affect irrigation requirements for all the three cropping seasons: Rabi, Kharif-I, Kharif-II. Increase in temperature will scale up irrigation demands by $200 \mathrm{Mm} 3$ for March alone. Currently, the irrigation and fisheries sectors compete for water. Since the solubility of oxygen in water decreases with higher temperature reported by Asian Development Bank (2004), it could be a problem for fisheries. If river flow is reduced during the dry season, this problem will be worse. Moreover, freshwater migratory fish hatchlings will face a survival problem in the southwestern part of Bangladesh because of increased salinity from sea level rise. Mitigation Policy Framework; Bangladesh should adopt a number of policies where environment issues will address. Important policy documents throughout the analysis are:

1. Maintenance of the ecological balance and overall progress and development of the country through protection and improvement of the environment;

2. Protection of the country against natural disasters;

3. Identification and control of all types of activities related to pollution and degradation of environment;

4. Undertaking environmentally development programs in all sectors including

agriculture, industry, health, energy, water, land, forest.

Vulnerabilities assessment, disaster management, enhanced structure design, institutional reform and anti extreme climate engineering are some feasible adaptation policies in Bangladesh. A complete climate policy should encompass both mitigation and adaptation to climate change due to global warming.

\section{Objective of this study}

A comparative study of changing pattern of seasonal temperature in Barisal and Khulna divisions of Bangladesh for 51 years

\section{Paired Samples Test}




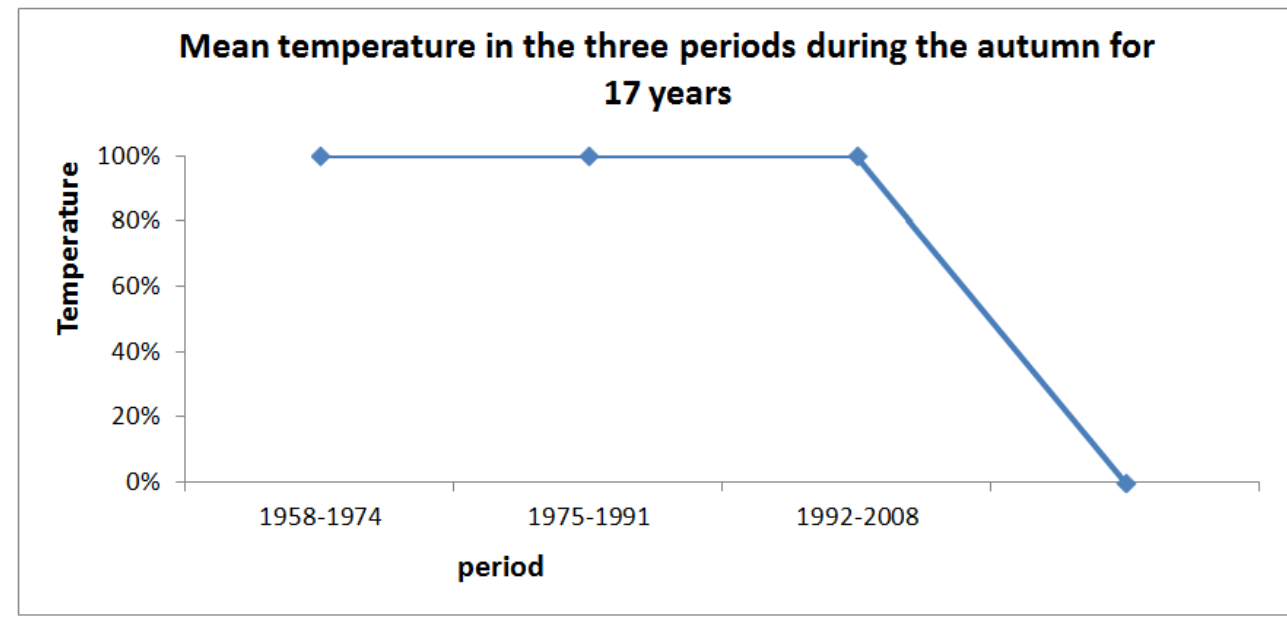

Fig. 4.1 Trend of seasonal yearly mean temperature in the three periods during the autumn for 17 year (1958-1974)

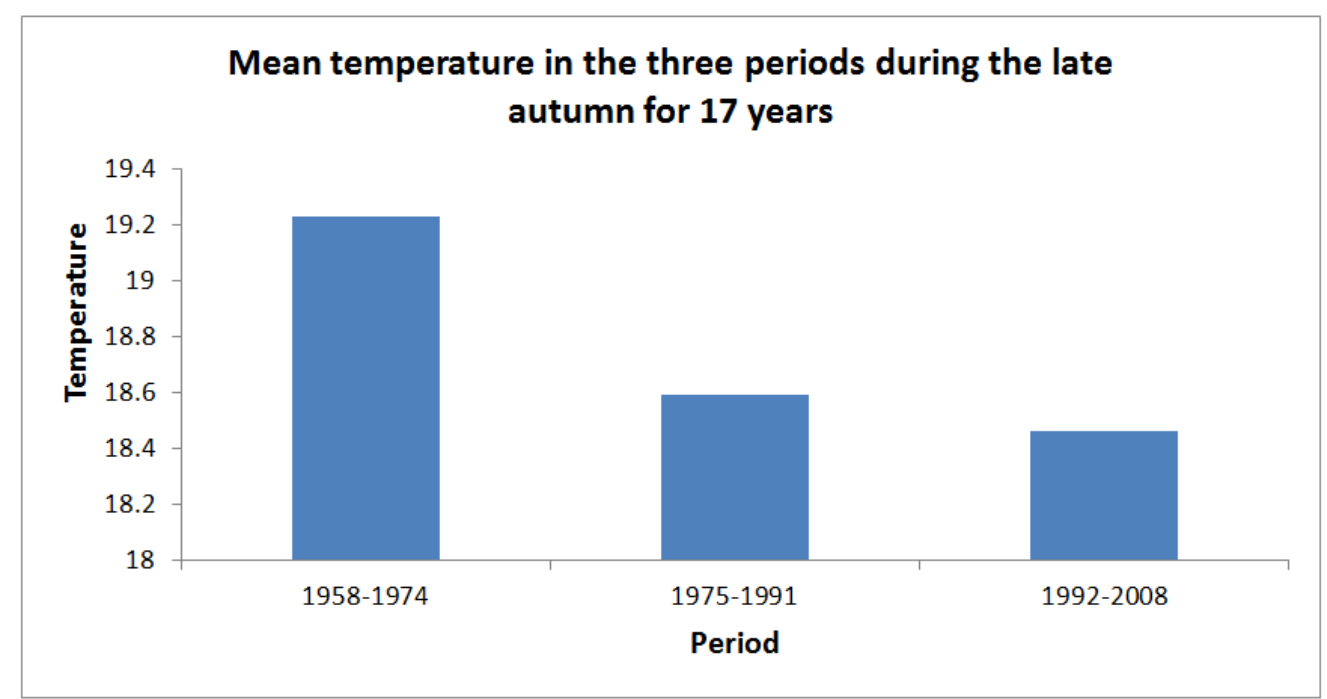

Fig.4.2 Trend of seasonal yearly mean temperature in the three periods during the late autumn for 17 year (1958-1974)

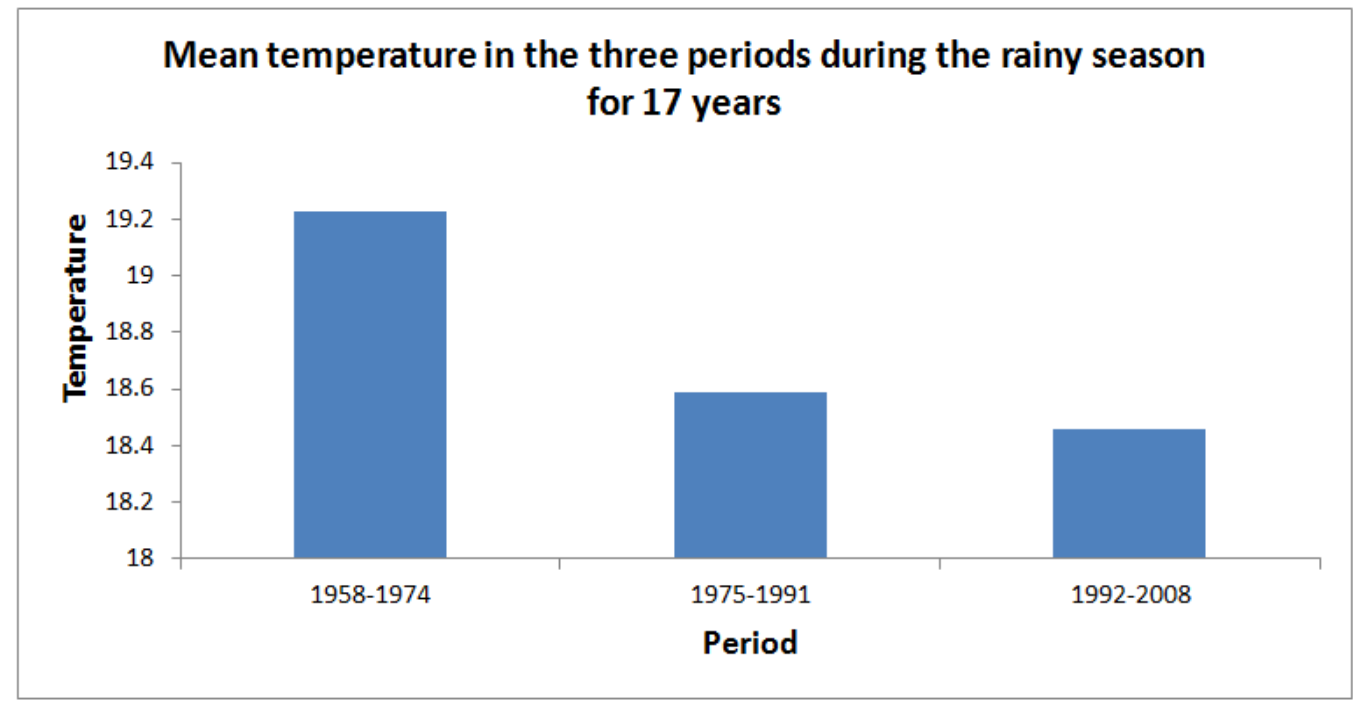

Fig. 4.3 Trend of seasonal yearly mean temperature in the three periods during the rainy season for 17 year $(1958-1974)$ 


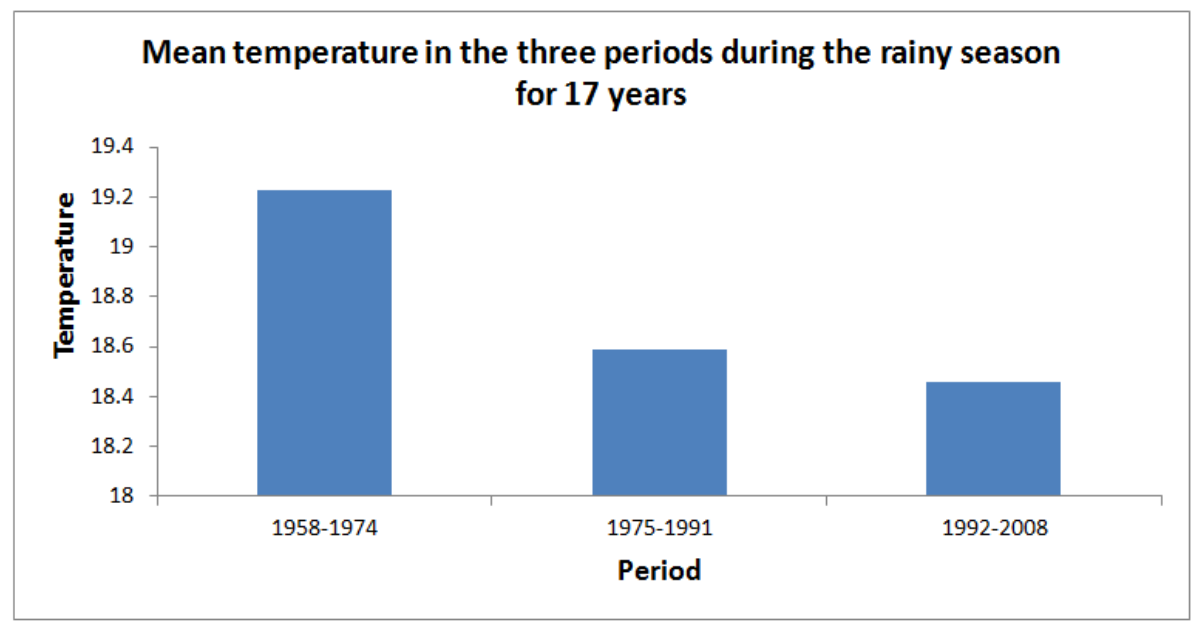

Fig. 4.4 Trend of seasonal yearly mean temperature in the three periods during the rainy season for 17 year (1958-1974)

Fig. 4.7 Trend of seasonal yearly mean temperature in the three periods during the spring for 17 year (19581974)

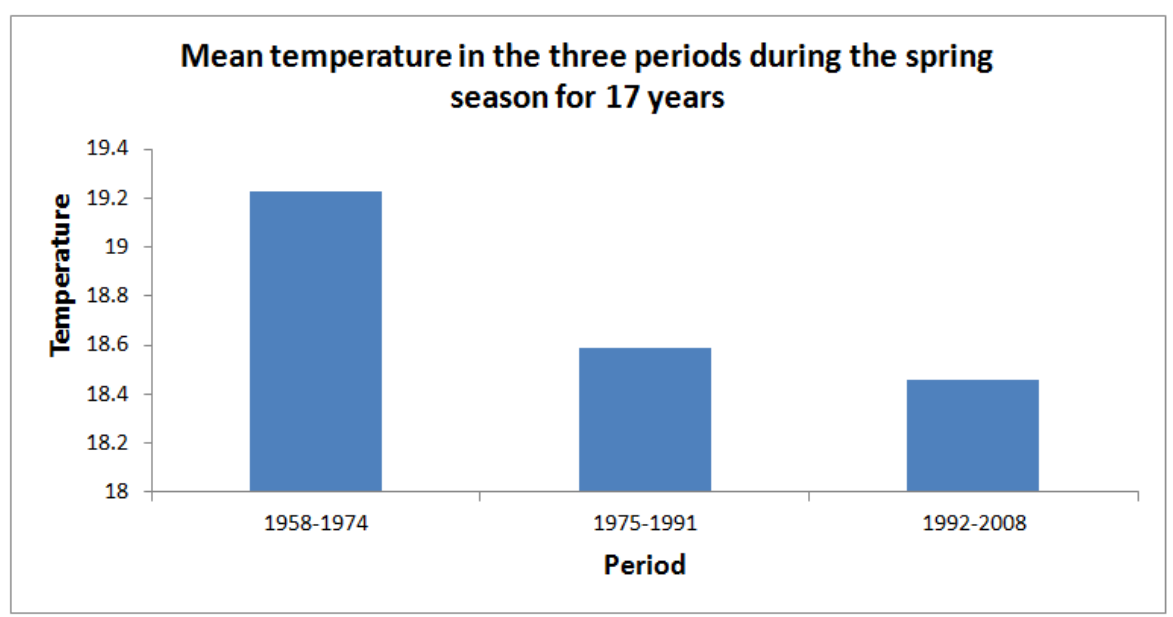

Fig. 4.8 Trend of seasonal yearly mean temperature in the three periods during the spring for 17 year (1958-1974)

Fig. 4.9 Trend of seasonal yearly mean temperature in the three periods during the summer season for 17 year (1958-1974)

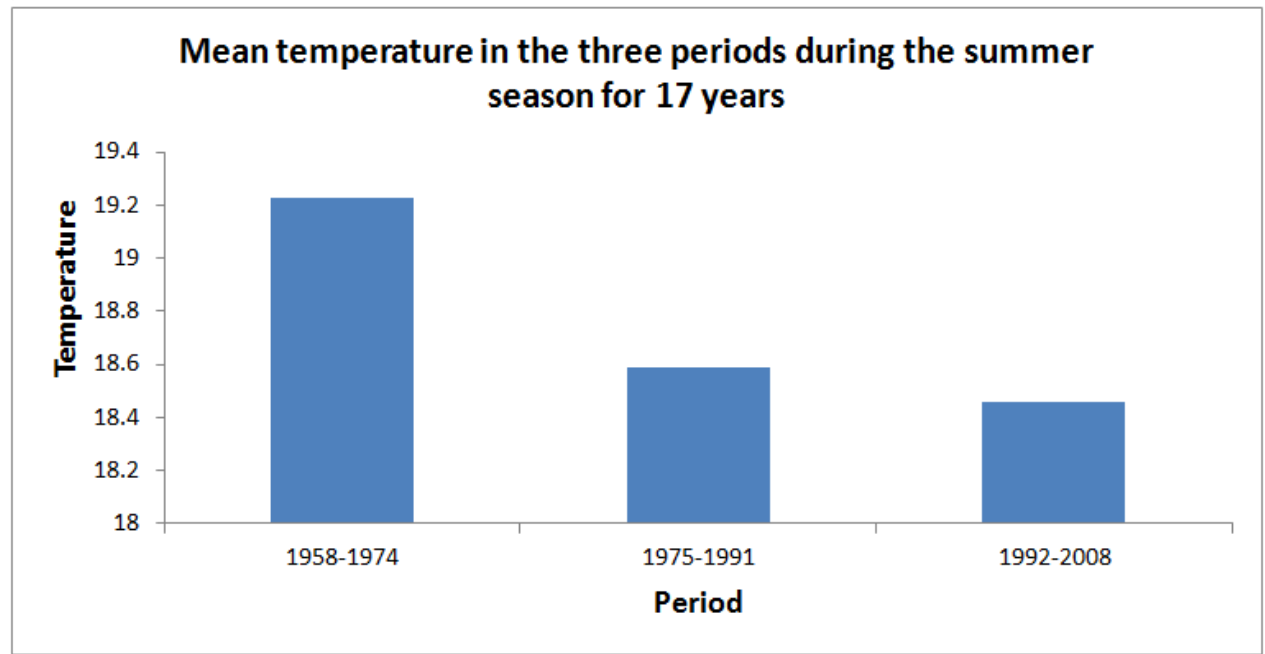

Fig. 4.10 Trend of seasonal yearly mean temperature in the three periods during the summer season for 17 year (1958-1974) 
Fig. 4.11 Trend of seasonal yearly mean temperature in the three periods during the winter season for 17 year (1958-1974)

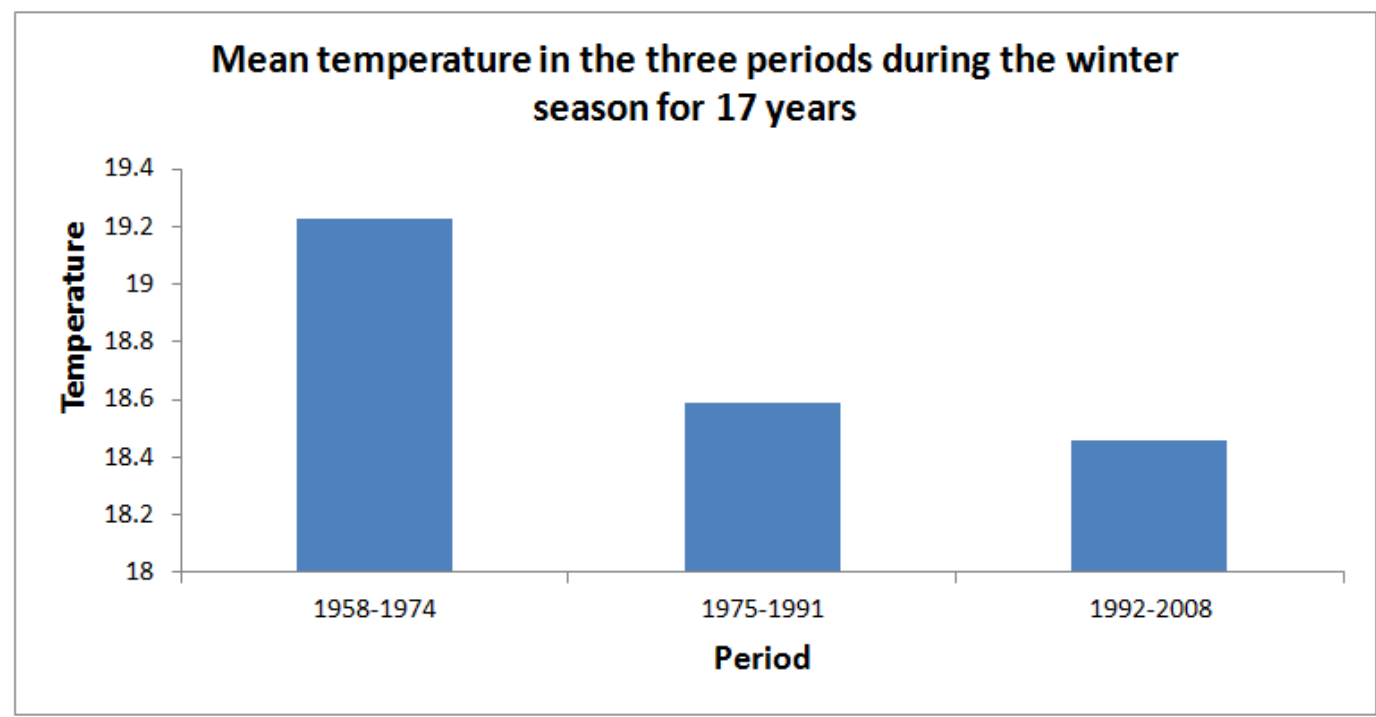

Fig. 4.12 Trend of seasonal yearly mean temperature in the three periods during the winter season for 17 year $(1958-1974)$

Table 4.1 Mean value of three periods for temperature data series in Barisal division during six Bengali seasons

\begin{tabular}{|c|c|c|c|c|}
\hline & & \multicolumn{3}{|c|}{ Period } \\
\hline Parameter & Bengali Season & $\begin{array}{c}\text { Average temperature } \\
(1958-1974)\end{array}$ & $\begin{array}{c}\text { Average temperature } \\
(1975-1991)\end{array}$ & $\begin{array}{c}\text { Average temperature } \\
(1992-2008)\end{array}$ \\
\hline & Autumn & 28.13 & 28.05 & 28.20 \\
\hline & Late autumn & 23.92 & 23.51 & 23.66 \\
\hline $\begin{array}{c}\text { Daily average } \\
\text { temperature }\end{array}$ & Rainy season & 28.22 & 28.09 & 28.29 \\
\hline & Spring & 25.66 & 25.39 & 25.45 \\
\hline & Summer & 29.23 & 28.53 & 28.90 \\
\hline & Winter & 19.45 & 18.59 & 18.46 \\
\hline
\end{tabular}

Table 4.2 Mean value of three periods for temperature data series in Khulna division during six Bengali seasons

\begin{tabular}{|c|c|c|c|c|}
\hline & & \multicolumn{3}{|c|}{ Period } \\
\hline Parameter & Bengali Season & $\begin{array}{c}\text { Average temperature } \\
(1958-1974)\end{array}$ & $\begin{array}{c}\text { Average temperature } \\
(1975-1991)\end{array}$ & $\begin{array}{c}\text { Average temperature } \\
(1992-2008)\end{array}$ \\
\hline & Autumn & 27.688 & 28.449 & 28.69 \\
\hline & Late autumn & 23.796 & 24.252 & 24.08 \\
\hline $\begin{array}{c}\text { Daily average } \\
\text { temperature }\end{array}$ & Rainy season & 28.002 & 28.505 & 28.91 \\
\hline & Spring & 26.33 & 26.09 & 2509 \\
\hline & Summer & 30.34 & 29.22 & 29.65 \\
\hline & Winter & 19.59 & 19.22 & 18.802 \\
\hline
\end{tabular}

Table 4.3: Result of t-test showing the mean difference between two periods of temperature in Barisal division during six Bengali seasons

\begin{tabular}{|c|c|c|c|c|c|}
\hline Parameter & & Period & T-statistic & p-value & Significance level (\%) \\
\hline & & (1958-1974) and (1975-1991) & 2.828 & 0.01 & 1 \\
\hline & Summer & (1975-1991) and (1992-2008) & -2.30 & 0.035 & 5 \\
\hline & & $(1958-1974)$ and (1992-2008) & 1.299 & 0.212 & 3 \\
\hline & & (1058-1074) and (1075-1091) & 0.037 & 0362 & 1 \\
\hline & $\begin{array}{l}\text { Rainy } \\
\text { season }\end{array}$ & (1975-1991) and (1992-2008) & -2.034 & 0.059 & 3 \\
\hline & & $(1958-1974)$ and (1992-2008) & -0.662 & 0.517 & 2 \\
\hline & & (1958-1974) and (1975-1991) & 0.585 & 0.567 & 4 \\
\hline & Autumn & $(1975-1991)$ and (1992-2008) & -1.243 & 0.232 & 3 \\
\hline & & (1958-1974) and (1992-2008) & 0.580 & 0.570 & 1 \\
\hline Daily average & Late & (1958-1974) and (1975-1991) & 1.203 & 0.247 & 2 \\
\hline
\end{tabular}


Comparative study of changing pattern of temperature for various periods of time

\begin{tabular}{|c|c|c|c|c|c|}
\hline temperature & autumn & & & & \\
\hline & & $(1975-1991)$ and (1992-2008) & -0.745 & 0.467 & 2 \\
\hline & & $(1958-1974)$ and (1992-2008) & 0.974 & 0.344 & 1 \\
\hline & & (1958-1974) and (1975-1991) & 2.039 & 0.058 & 1 \\
\hline & Winter & (1975-1991) and (1992-2008) & 0.904 & 0.380 & 3 \\
\hline & & (1958-1974) and (1992-2008) & 2.483 & 0.024 & 2 \\
\hline & & (1958-1974) and (1975-1991) & 0.814 & 0.428 & 3 \\
\hline & Spring & (1975-1991) and (1992-2008) & -0.186 & 0.855 & 1 \\
\hline & & (1958-1974) and (1992-2008) & 0.562 & 0.582 & 2 \\
\hline
\end{tabular}

Table 4.4: Result of t-test showing the mean difference between two periods of temperature in Khulna division during six Bengali seasons

\begin{tabular}{|c|c|c|c|c|c|}
\hline \multirow[t]{11}{*}{ Parameter } & & Period & T-statistic & p-value & Significance level (\%) \\
\hline & & $\begin{array}{c}(1958-1974) \text { and } \\
(1975-1991)\end{array}$ & 2.88 & 0.01 & 1 \\
\hline & Summer & (1975-1991) and (1992-2008) & -1.853 & 0.08 & 2 \\
\hline & & (1958-1974) and (1992-2008) & 2.205 & 0.042 & 3 \\
\hline & & (1958-1974) and (1975-1991) & -3.072 & 0.008 & 2 \\
\hline & Rainy season & $(1975-1991)$ and (1992-2008) & -3.63 & 0.002 & 1 \\
\hline & & $(1958-1974)$ and (1992-2008) & -5.010 & 0.000 & 3 \\
\hline & & & & & \\
\hline & & (1958-1974) and (1975-1991) & -3.65 & 0.002 & 1 \\
\hline & Autumn & (1975-1991) and (1992-2008) & -5.07 & 0.000 & 2 \\
\hline & & (1958-1974) and (1992-2008) & -1.944 & 0.070 & 3 \\
\hline \multirow{9}{*}{$\begin{array}{c}\text { Daily average } \\
\text { temperature }\end{array}$} & Late autumn & $(1958-1974)$ and (19751991) & -0.975 & 0.344 & 2 \\
\hline & & (1975-1991) and (1992-2008) & 0.474 & 0.642 & 3 \\
\hline & & (1958-1974) and (1992-2008) & -1.027 & 0.320 & 1 \\
\hline & & (1958-1974) and (1975-1991) & 1.031 & 0.318 & 2 \\
\hline & Winter & (1975-1991) and (1992-2008) & 1.483 & 0.158 & 1 \\
\hline & & (1958-1974) and (1992-2008) & 3.99 & 0.001 & 1 \\
\hline & & (1958-1974) and (1975-1991) & 0.678 & 0.508 & 1 \\
\hline & Spring & (1975-1991) and (1992-2008) & 0.515 & 0.613 & 1 \\
\hline & & (1958-1974) and (1992-2008) & 1.403 & 0.180 & 2 \\
\hline
\end{tabular}

Table 4.5 Estimate value of t-statistic for slope and p-value for different regression equations in Barisal division for summer temperature

\begin{tabular}{|c|c|c|c|c|c|}
\hline Data series & $\mathrm{df}$ & Regression equation & $\begin{array}{l}\text { t-Statistics for } \\
\text { slope }\end{array}$ & P-value & $\begin{array}{l}\text { Remarks } \\
\text { (change) }\end{array}$ \\
\hline 1958-1974 (Period:1) & 16 & $y_{1}=-0.1139 t+30.264$ & -3.45 & 0.000 & $(-)^{* * *}$ \\
\hline 1975-1991(Period:2) & 16 & $y_{2}=0.0308 t+28.255$ & 1.40 & 0.000 & $(+)^{* * *}$ \\
\hline 1992-2008(Period:3) & 16 & $y_{3}=0.0248 t+28.681$ & 1.034 & 0.000 & $(+)^{* * *}$ \\
\hline
\end{tabular}

Note: (+) indicates increasing trend; $* *$ and $* * *$ indicate significance level $1 \%$ and $0.1 \%$.

Table 4.6 Estimate value of t-statistic for slope and p-value for different regression equations in Barisal division for rainy season temperature

\begin{tabular}{|c|c|c|c|c|c|}
\hline Data series & df & Regression equation & t-Statistics for slope & P-value & $\begin{array}{c}\text { Remarks } \\
\text { (change) }\end{array}$ \\
\hline 1958 -1974 (Period:1) & 16 & $y_{1}=-0.049 t+28.661$ & -2.801 & 0.013 & $(+)^{* * *}$ \\
\hline $1975-1991$ (Period:2) & 16 & $y_{2}=0.0391 t+27.747$ & 2.79 & 0.14 & $(+)^{* * *}$ \\
\hline $1992-2008$ (Period:3) & 16 & $y_{3}=0.0112 t+28.194$ & 1.080 & 0.297 & $(+)^{* * *}$ \\
\hline
\end{tabular}

Note: (+) indicates increasing trend; $* *$ and $* * *$ indicate significance level $1 \%$ and $0.1 \%$. 
Table 4.7 Estimate value of t-statistic for slope and p-value for different regression equations in Barisal division for autumn temperature

\begin{tabular}{|c|c|c|c|c|c|}
\hline Data series & $\mathrm{df}$ & Regression equation & $\begin{array}{c}\text { t-Statistics for } \\
\text { slope }\end{array}$ & P-value & $\begin{array}{c}\text { Remarks } \\
\text { (change) }\end{array}$ \\
\hline 1958-1974 (Period:1) & 16 & $y_{1}=-0.0422 t+28.5$ & -1.983 & 0.055 & $(+)^{* * *}$ \\
\hline 1975-1991(Period:2) & 16 & $y_{2}=0.0138 t+27.932$ & 0.847 & 0.411 & $(+)^{* * *}$ \\
\hline 1992-2008(Period:3) & 16 & $y_{3}=0.0004 t+28.204$ & -0.033 & 0.974 & $(+)^{* * *}$ \\
\hline
\end{tabular}

Note: (+) indicates increasing trend; $* *$ and $* * *$ indicate significance level $1 \%$ and $0.1 \%$.

Table 4.8 Estimate value of t-statistic for slope and p-value for different regression equations in Barisal division for late autumn temperature

\begin{tabular}{|c|c|c|c|c|c|}
\hline Data series & $\mathrm{df}$ & Regression equation & $\begin{array}{c}\text { t-Statistics for } \\
\text { slope }\end{array}$ & $\begin{array}{c}\text { P-value } \\
\text { Remarks } \\
\text { (change) }\end{array}$ \\
\hline 1958-1974 (Period:1) & 16 & $y_{1}=-0.058 t+24.448$ & -1.065 & 0.304 & $(+)^{* * *}$ \\
\hline $1975-1991$ (Period:2) & 16 & $y_{2}=-0.0345 t+23.828$ & -1.022 & 0.323 & $(+)^{* * *}$ \\
\hline $1992-2008$ (Period:3) & 16 & $y_{3}=-0.0073 t+23.731$ & -0.326 & 0.749 & $(+)^{* * *}$ \\
\hline
\end{tabular}

Note: (+) indicates increasing trend; $* *$ and $* * *$ indicate significance level $1 \%$ and $0.1 \%$.

Table 4.9 Estimate value of t-statistic for slope and p-value for different regression equations in Barisal division for winter temperature

\begin{tabular}{|c|c|c|c|c|c|}
\hline Data series & $\mathrm{df}$ & Regression equation & $\begin{array}{c}\text { t-Statistics for } \\
\text { slope }\end{array}$ & P-value & $\begin{array}{c}\text { Remarks } \\
\text { (change) }\end{array}$ \\
\hline 1958-1974 (Period:1) & 16 & $y_{1}=-0.0816 t+20184$ & -1.057 & 0.307 & $(+)^{* * *}$ \\
\hline 1975-1991(Period:2) & 16 & $y_{2}=0.0259 t+18.362$ & 1.035 & 0.317 & $(+)^{* * *}$ \\
\hline 1992-2008(Period:3) & 16 & $y_{3}=0.033 t+18.164$ & 1.415 & 0.178 & $(+)^{* * *}$ \\
\hline
\end{tabular}

Note: (+) indicates increasing trend; $* *$ and $* * *$ indicate significance level $1 \%$ and $0.1 \%$.

Table 4.10 Estimate value of t-statistic for slope and p-value for different regression equations in Barisal division for spring temperature

\begin{tabular}{|c|c|c|c|c|c|}
\hline Data series & $\mathrm{df}$ & Regression equation & $\begin{array}{c}\text { t-Statistics for } \\
\text { slope }\end{array}$ & P-value & $\begin{array}{c}\text { Remarks } \\
\text { (change) }\end{array}$ \\
\hline 1958-1974 (Period:1) & 16 & $y_{1}=-0.0888 t+26.479$ & -2.273 & .039 & $(+)^{* * *}$ \\
\hline 1975-1991(Period:2) & 16 & $y_{2}=0.0169 t+25.197$ & 0.446 & 0.662 & $(+)^{* * *}$ \\
\hline $1992-2008$ (Period:3) & 16 & $y_{3}=0.0065 t+25.337$ & 0.169 & 0.888 & $(+)^{* * *}$ \\
\hline
\end{tabular}

Note: $(+)$ indicates increasing trend; $* *$ and $* * *$ indicate significance level $1 \%$ and $0.1 \%$

Table 4.11 Estimate value of t-statistic for slope and p-value for different regression equations in Khulna division for summer temperature

\begin{tabular}{|c|c|c|c|c|c|}
\hline Data series & $\mathrm{df}$ & Regression equation & $\begin{array}{c}\text { t-Statistics for } \\
\text { slope }\end{array}$ & P-value & $\begin{array}{c}\text { Remarks } \\
\text { (change) }\end{array}$ \\
\hline 1958-1974 (Period:1) & 16 & $y_{1}=0.0204 t+30.164$ & 0.314 & 0.758 & $(+)^{* * *}$ \\
\hline $\begin{array}{c}1975-1991 \\
\text { (Period:2) }\end{array}$ & 16 & $y_{2}=-0.0422 t+29.603$ & -1.327 & 0.204 & $(+)^{* * *}$ \\
\hline $\begin{array}{c}1992-2008 \\
\text { (Period:3) }\end{array}$ & 16 & $y_{3}=0.0462 t+29.235$ & 1.999 & 0.054 & $(+)^{* * *}$ \\
\hline
\end{tabular}

Note: (+) indicates increasing trend; $* *$ and $* * *$ indicate significance level $1 \%$ and $0.1 \%$. 
Table 4.12 Estimate value of t-statistic for slope and p-value for different regression equations in Khulna division for rainy season temperature

\begin{tabular}{|c|c|c|c|c|c|}
\hline Data series & $\mathrm{df}$ & Regression equation & t-Statistics for slope & P-value & $\begin{array}{c}\text { Remarks } \\
\text { (change) }\end{array}$ \\
\hline $1958-1974$ (Period:1) & 16 & $y_{1}=-0.0253 t+28.29$ & -0.942 & 0.361 & $(+)^{* * *}$ \\
\hline $1975-1991$ (Period:2) & 16 & $y_{2}=0.033 t+28.191$ & 1.99 & 0.65 & $(+)^{* * *}$ \\
\hline $1992-2008$ (Period:3) & 16 & $y_{3}=0.0258 t+28.652$ & 2.119 & 0.051 & $(+)^{* * *}$ \\
\hline
\end{tabular}

Note: $(+)$ indicates increasing trend; $* *$ and $* * *$ indicate significance level $1 \%$ and $0.1 \%$.

Table 4.13 Estimate value of t-statistic for slope and p-value for different regression equations in Khulna division for autumn temperature

\begin{tabular}{|c|c|c|c|c|c|}
\hline Data series & $\mathrm{df}$ & Regression equation & $\begin{array}{c}\text { t-Statistics for } \\
\text { slope }\end{array}$ & P-value & $\begin{array}{c}\text { Remarks } \\
\text { (change) }\end{array}$ \\
\hline 1958-1974 (Period:1) & 16 & $y_{1}=-0.0004 t+27.729$ & 0.0001 & 0.999 & $(+)^{* * *}$ \\
\hline 1975-1991(Period:2) & 16 & $y_{2}=-0.0018 t+28.492$ & .035 & 0.972 & $(+)^{* * *}$ \\
\hline $1992-2008$ (Period:3) & 16 & $y_{3}=0.0106 t+28.598$ & 0.801 & 0.436 & $(+)^{\text {*** }}$ \\
\hline
\end{tabular}

Note: (+) indicates increasing trend; $* *$ and $* * *$ indicate significance level $1 \%$ and $0.1 \%$.

Table 4.14 Estimate value of t-statistic for slope and p-value for different regression equations in Khulna division for late autumn temperature

\begin{tabular}{|l|l|l|l|l|l|}
\hline Data series & $\mathrm{df}$ & Regression equation & $\begin{array}{l}\text { t-Statistics for } \\
\text { slope }\end{array}$ & P-value & $\begin{array}{l}\text { Remarks } \\
\text { (change) }\end{array}$ \\
\hline 1958-1974 (Period:1) & 16 & $y_{1}=0.0798 t+23.078$ & 1.401 & 0.181 & $(+)^{* * *}$ \\
\hline 1975-1991(Period:2) & 16 & $y_{2}=-0.164 t+25.735$ & -3.746 & 0.002 & $(+)^{* * *}$ \\
\hline 1992-2008(Period:3) & 16 & $y_{3}=0.0034 t+24.052$ & 0.145 & 0.887 & $(+)^{\text {*** }}$ \\
\hline
\end{tabular}

Note: $(+)$ indicates increasing trend; $* *$ and $* * *$ indicate significance level $1 \%$ and $0.1 \%$.

Table 4.15 Estimate value of t-statistic for slope and p-value for different regression equations in Khulna division for winter temperature

\begin{tabular}{|c|c|c|c|c|c|}
\hline Data series & $\mathrm{df}$ & Regression equation & $\begin{array}{c}\mathrm{t} \text {-Statistics for } \\
\text { slope }\end{array}$ & P-value & $\begin{array}{c}\text { Remarks } \\
\text { (change) }\end{array}$ \\
\hline 1958-1974 (Period:1) & 16 & $y_{1}=0.124 t+18.47$ & 5.126 & 0.000 & $(+)^{* * *}$ \\
\hline 1975-1991(Period:2) & 16 & $y_{2}=-0.114 t+20.26$ & -2.589 & 0.021 & $(+)^{* * *}$ \\
\hline $1992-2008$ (Period:3) & 16 & $y_{3}=0.053 t+18.31$ & 2.161 & .047 & $(+)^{* * *}$ \\
\hline
\end{tabular}

Note: (+) indicates increasing trend; $* *$ and $* * *$ indicate significance level $1 \%$ and $0.1 \%$.

Table 4.16 Estimate value of t-statistic for slope and p-value for different regression equations in Khulna division for spring temperature

\begin{tabular}{|c|c|c|c|c|c|}
\hline Data series & df & Regression equation & $\begin{array}{c}\text { t-Statistics for } \\
\text { slope }\end{array}$ & P-value & $\begin{array}{c}\text { Remarks } \\
\text { (change) }\end{array}$ \\
\hline 1958-1974 (Period:1) & 16 & $y_{1}=0.043 t+25.94$ & 0.974 & 0.346 & $(+)^{* * *}$ \\
\hline 1975-1991(Period:2) & 16 & $y_{2}=-0.134 t+27.30$ & -2.624 & 0.019 & $(+)^{* * *}$ \\
\hline 1992-2008(Period:3) & 16 & $y_{3}=0.029 t+25.64$ & 0.77 & 0.453 & $(+)^{* * *}$ \\
\hline
\end{tabular}

Note: $(+)$ indicates increasing trend; $* *$ and $* * *$ indicate significance level $1 \%$ and $0.1 \%$. 


\section{Conclusions}

Monthly maximum, minimum and mean temperature shows a positive trend over Bangladesh. Increase of monthly maximum temperature is $0.600 \mathrm{C}$, monthly minimum temp is $1.39 \mathrm{OC}$ and monthly mean temperature is $0.790 \mathrm{C}$ per 100 years. Maximum increase of monthly maximum temperature has occurred in November at $2.050 \mathrm{C}$ and monthly minimum temperature has occurred in February at $2.730 \mathrm{C}$ in 100 years. The highest increase of monthly maximum temperature has occurred as $1.10 \mathrm{C}$ per 100 years at Dhaka and monthly minimum temperature has occurred as $-0.2 \mathrm{OC}$ per 100 years at Rajshahi. It has clearly found that maximum temperature has been increased dramatically over the last 21 years period. Monthly maximum, minimum and mean temperature has shown positive increase with a rate of $4.490 \mathrm{C}, 2.980 \mathrm{C}$ and $2.060 \mathrm{C}$ per 100 years respectively during the period of last 21 years (1990-2010). Increase of winter temperature can reduce the environmental suitability for wheat, potato and other temperate crops grown in Rabi season. Implications for Agriculture and Fisheries; in Bangladesh, the largest demand for both surface and ground water is to support irrigation in the dry months. Changes in climate may affect irrigation requirements for all the three cropping seasons: Rabi, Kharif-I, Kharif-II. Increase in temperature will scale up irrigation demands by $200 \mathrm{Mm} 3$ for March alone. Currently, the irrigation and fisheries sectors compete for water. Since the solubility of oxygen in water decreases with higher temperature reported by Asian Development Bank (2004), it could be a problem for fisheries. If river flow is reduced during the dry season, this problem will be worse. Moreover, freshwater migratory fish hatchlings will face a survival problem in the southwestern part of Bangladesh because of increased salinity from sea level rise.

Mitigation Policy Framework; Bangladesh should adopt a number of policies where environment issues will address. Important policy documents throughout the analysis are:

1. Maintenance of the ecological balance and overall progress and development of the country through protection and improvement of the environment;

2. Protection of the country against natural disasters;

3. Identification and control of all types of activities related to pollution and degradation of environment;

4. Undertaking environmentally development programs in all sectors including

agriculture, industry, health, energy, water, land, forest Vulnerabilities assessment, disaster management, enhanced structure design, institutional reform and anti extreme climate engineering are some feasible adaptation policies in

Bangladesh. A complete climate policy should encompass both mitigation and adaptation to climate change due to global warming.

\section{Conclusion}

Annual total rainfall of last ten years (2005-2015) did not show any significant changing trends. Highest amountof rainfall occurred at all station in 2007. The monthlytotal country average rainfall was highest in July followedby June, Augustand September and lowest in January followed by December and February. The highest rainfall occurs in monsoon season (June- September) and lowest rainfall in winter season (DecemberFebruary). Summer monsoon rainfall widely varies over different parts of the country with lowest over Rajshahi and highest over Chittagong of the country followed by Sylhet. Barisal has a tropical climate. In winter, there is much less rainfall in Barisal than in summer. This location is classified as Aw by Köppen and Geiger. In Barisal, the average annual temperature is $25.9^{\circ} \mathrm{C}$. The average annual rainfall is $2184 \mathrm{~mm}$.

This article is about the city. For the division, see Khulna Division. For the district, see Khulna District. For the subdistrict, see Khulna Kotwali Thana.

\section{References}

[1]. Bank AD (2004) Country Environmental Analysis Bangladesh. 3rd draft, pp 17

[2]. Chan KL (2006) Climate issues in Hong Kong: Mitigation and Adaptation. pp 4

[3]. Chowdhury MHK, Debsharma SK (1992) Climate change in Bangladesh - A statistical review. Report on IOC-UNEP workshop on impacts of sea level rise due to global warming, NOAMI, held during 16-19 November 1992, Bangladesh.

[4]. BMD Bangladesh

[5]. Divya, Mehrotra R (1995) Climate Change and hydrology with emphasis on the Indian subcontinent. J Hydro Sciences 40, pp 231241 